Jan W. Żelazny

Pontifical University of John Paul II in Kraków

\title{
The legend of Shirin in Syriac sources. A warning against caesaropapism?
}

Why was Syriac Christianity not an imperial Church? Why did it not enter into a relationship with the authorities? This can be explained by pointing to the political situation of that community. I think that one of the reasons was bad experiences from the time of Chosroes II.

\section{The Story of Chosroes II}

The life of Chosroes II Parviz is a story of rise and fall. Although Chosroes II became later a symbol of the power of Persia and its ancient independence, he encountered numerous difficulties from the very moment he ascended the throne. Chosroes II took power in circumstances that today remain obscure - as it was frequently the case at the Persian court - and was raised to the throne by a coup. The rebel was inspired by an attempt of his father, Hormizd IV, to oust one of the generals, Bahram Cobin, which provoked a powerful reaction among the Persian aristocracy. The question concerning Chosroes II's involvement in the conspiracy still remains unanswered; however, Chosroes II was raised to the throne by the same magnates who had rebelled against his father. Soon after, Hormizd IV died in prison in ambiguous circumstances. The Arabic historian, al-Tabari, claimed that Chosroes was oblivious of the rebellion. However, al-Tabari works were written several centuries later, at a time when the legend of the shah was already deeply rooted in the consciousness of the people. A Greek historian, Theophylaktos Simokatta, appears to have been more familiar with these events, and claimed in his works that Chosroes II had known about the plot. Soon after being crowned, Chosroes II, later called "the Ever Victorious," had to struggle to keep the throne. At the same time, General Bahram Cobin, allegedly descended from the Arsacid dynasty, proclaimed himself 
king, and the shah was probably defeated in the battle of Ctesiphon and was forced to flee to the lands of the Eastern Roman Empire to avoid imprisonment and death. The place of his exile is still questionable; the following cities are mentioned in historical sources: Dara, Hierapolis (with Domitian of Melitene, a relative of Maurice, residing as a bishop) and Edessa. It is also probable that Chosroes II frequently changed the place of residence in fear of assassination. Chosroes II submitted himself to the care of Emperor Maurice (591). He started exchanging letters with the Emperor, proposing territorial concessions (regained sovereignty over Mesopotamia with Nisibis; restoration of borders from before the defeat of Julian the Apostate) and in return, asked Emperor Maurice to assist Chosroes in regaining his throne. A similar proposal was submitted by Bahram, who proclaimed himself King of Persia on the 9 May 590. According to Theophylaktos, the arguments of Chosroes prevailed because of the reference to his legitimacy to the throne. Historians claim that it was the decisive argument that tipped the scales in favour of the ousted shah. Emperor Maurice decided to support Chosroes II as the legitimate heir to the throne. The Byzantine Empire provided financial and military support for the exiled shah.

\section{Maria and Shirin}

According to Ferdowsi and other authors, who relied on The Book of Lords and similar Persian chronicles describing the history of the shahs written in the $7^{\text {th }}$ century, Chosroes II married Shirin, a Christian, when he resided in Hierapolis. It is claimed that Shirin came from Khuzestan (south-western Iran, according to Pseudo-Sebeos) or from the city of Kufa (northern Iraq). According to The Syriac Chronicle, ${ }^{1}$ Chosroes married two women when he lived under the protection of the Byzantine Empire, one of them named Maria, which was the daughter's name of the Byzantine Emperor Maurice. ${ }^{2}$ With the financial assistance of the Byzantine Emperor and military support of Narses, a Byzantine general, the shah returned to his homeland. One of the Greek generals, Madab, defeated Bahram in a battle and enabled Chosroes to triumphantly march into the capital city. The shah was accompanied by his family, children and wives (?), including Shirin. Some researchers, who analyse the writings of Evagrius,

\footnotetext{
${ }^{1}$ Die von Guidi herausgegebene syrische Chronik, übersetzt und commentiert von T. Nöldeke, Wien 1893, p. 10 (Sitzungsberichte Kaiserliche Akademie der Wissenschaften in Wien, 128).

${ }^{2} \mathrm{~W}$. Baum, Shirin. Christian, queen, myth of love. A woman of late antiquity. Historical reality and literary effect, Piscataway 2004, pp. 26-30. There are no grounds to support this legend as the Emperor did not have any daughter that would be capable of a marriage. Moreover, it is unlikely that the Emperor would consent to his daughter marrying a pagan. The claims of the shah being baptised are only fables. That's why this account should be rejected, although this fact is referred to by several ancient historians, including al-Tabari, The Syriac Chronicle of Pseudo-Dionysius of Tel-Mahre, or The Syriac Chronicle.
} 
claim that Chosroes and Shirin got married on this occasion. During the festivities in 591, celebrating the shah's victory, a peace treaty was signed with the Byzantine Empire. According to the Persian tradition, the coronation and celebrations of the victory over the usurper was an occasion for the followers of Chosroes to be rewarded and to punish his enemies. ${ }^{3}$

The return of the sovereign to Ctesiphon marked an era of overt support for Christians, as evidenced in nominations and rewards awarded during the coronation. Chosroes II was not the first shah who showed support for the followers of Christ. Some researchers claim that his father, Hormizd IV, supported various minority groups within the Empire and encountered the disapproval of the Persian aristocracy, who professed Zoroastrianism, an indigenous religion of the Persians. This might have contributed to his dethronement and death. This aversion paved the way for the overturn of Hormizd IV, and was one of the crucial factors in the coup by Bahram II, who claimed to be a defender of the tradition. However, since the return of the King of Kings to the throne he showed more support to the representatives of the Church of the East, the community from which Shirin came. The King of Kings bestowed upon them some important positions in administration, and surrounded himself by Christians at the court. Nevertheless, he refused to cooperate with the Church hierarchy. The old Catholicos, Isho Yahb I, supported Bahram II and was reluctant to welcome the return of a member of the Sassanid dynasty. He decided not to wait until the king arrived at the capital, escaped to Arabia and left the circles of power. Some cooperation between the shah and the Church was initiated by the monarch or a person close to the shah, from outside the Church hierarchy. This role is traditionally attributed to Shirin.

\section{The First Mention of Shirin - the History of the Cross from Reshaina}

Shirin is first mentioned in the documents of Evagrius Scholasticus and Theophylaktos, who write about the gifts of the Shah for the sanctuary of St. Sergius in Sergiopolis - Resafa. ${ }^{4}$ Both authors also claim that Shirin came from the Byzantine Empire. They described two separate events that followed in quick succession.

The first event was when two crosses were given to the Sanctuary. One of them was a gift from Theodora (Justinian?) robbed from Resafa by Chosroes I (the grandfather of Chosroes II), containing a part of the Holy Cross. The second cross was given as a sign of gratitude for the murder one of the shah's adversaries.

\footnotetext{
${ }^{3}$ According to al-Tabari, mainly the Jews who were dissatisfied with the prevalence of Christians at the shah's court.

${ }^{4}$ Evagrius Scholasticus, Book 6, Chapter XXI, $276 f$.
} 
The gift was offered according to the do ut des formula, which was quite popular at that time. Please note that the gift was offered as thanksgiving for murder, which revealed that the Persian king's philosophy was far from being truly Christian.

The second gift, another cross and a monetary gift, was related to the King of Kings' supplication for a fortunate childbirth for Shirin. This took place before the year 592. When St. Sergius satisfied the shah's wish, Chosroes II made another gift the next year - a thanksgiving stone for the birth of the King's son. This piece of information is perhaps related to the other writings of Theophylaktos that differ from what other authors' reports. Namely, Theophylaktos claimed that in addition to extending gifts to St. Sergius, Chosroes II also formally married Shirin, a Christian. The other alleged wife of the Shah, Maria, is not mentioned in any documents dating back to these events. Note that the story of Maria and the alleged conflict between both wives of the shah, both Christians, was first mentioned in the Christian sources dating back to ca. the $8^{\text {th }}$ century (The Syriac Chronicle and the Chronicle of Seert). The story of the shah's marriage with Maria is associated mainly with the writings of Patriarch Eutychius of Antioch from the $10^{\text {th }}$ century, who wrote the story of the christening of Chosroes II (the Byzantine Emperor Maurice was supposed to refuse to consent to the marriage of his daughter with a pagan, and the Shah was baptised).

\section{Election of a new Catholicos}

In 596, after the death of Isho Yahba I in Hira (where he fled from the shah and dwelt under the protection of a Christian Arabian king from the Ghassanid dynasty), the bishops gathered in the palace of Shirin in Ctesiphon. They intended to elect a new Catholicos, but the shah commanded them to appoint Sabrisho', a 72-year-old monk. It remains unclear what reason was behind this choice. In some later legend the shah was said to have a prophetic dream during which he saw Sabrisho' prophesying his victory in a battle against another rebellion led by one of the king's relatives. ${ }^{5}$ Many bishops undeniably questioned the appointment of Sabrisho'. The reason was not because he was a monk. Virtually, all bishops of the Assyrian Church of the East were monks even if their stay at a monastery was rather a formality and related only to the ordinations. Sabrisho' was notorious for his tenacity. His appointment was contrary to the interests of the Church of the East from then on; the power over the Church was vested in the hands of the monarch. Moreover, the bishops only reluctantly countenanced a monk as the new Catholicos of Ctesiphon, who was known for his asceticism, for being a representative of the people, a man who deserved respect; however, he did not deserve to be awarded the highest

\footnotetext{
${ }^{5}$ Another version refers to the prophesy of victory over Bahram Cobin.
} 
office in the opinion of the member of higher orders of clergy. Sabrisho' was the Catholicos until his death in 604 and attempted to keep balance between the life of the Church and the shah's demands, which was by no means easy. There are two factors, which should be closely examined. The first decision of the new patriarch was to express his gratitude to the monarch and to include the King of the Kings - a pagan - in the official prayers of the Church. ${ }^{6}$

The return of Chosroes II marked the beginning of a fascinating era of peace between two empires, which lasted until the murder of Emperor Maurice by Phokas. The relations between these two states now revived. Contacts between merchants and politicians from both empires became closer and more developed; economic and information exchange was thriving. Cultural intercourse also took place. It was a time of relief and restoration for both states, especially for Roman Syria devastated during the invasion of Chosroes I. Bishops were frequently sent as emissaries in diplomatic missions: Bishop Marutha represented the Byzantine Empire at the shah's court, and Milas of Senna represented Persia in Constantinople.

\section{The War against the Byzantine Empire}

In 602, a mutiny broke out in the Byzantine army that was decreed to stay for winter beyond the Danube. Under the command of Phokas, the troops mutinied against the emperor and attacked the capital. Then Maurice and his five sons were captured and murdered. Chosroes II used this coup as a pretext for a renewal of war against the Byzantine Empire. His armies soon invaded and plundered Syria and Palestine. Despite the fact that Heraclius, a son of the viceregal Exarch of Africa, successfully led a revolt against the unpopular usurper Phocas in 610 and became a Byzantine Emperor, Chosroes II still waged his war. It appeared that the dream about the restoration of the Achaemenid Empire, the Persian Empire, would finally come true. The shah conquered Egypt, his troops were attempting to capture Constantinople, and the European Avars were plundering the Danubian provinces. Nevertheless, Heraclius decided to rebuild and reform the military forces and moved into the Persian territory from the north, attacking and devastating the indigenous Persian territories, Media and the neighbouring lands. The exhausted Persian Empire attacked Constantinople, controlled Syria and at the same time it was defeated on its own territory.

${ }^{6}$ Das Buch der Synhados, oder, Synodicon orientale. Die Sammlung der Nestorianischen Konzilien, zusammengestellt im neunten Jahrhundert. Nach der Syrischen Handschrift, Museo Borgiano 82, der Vatikanischen Bibliothek, ubersetzt und erlautert, mit kritischen und historischen Anmerkungen, Namen- und Sachregistern [von] O. Braun, Amsterdam 1975, p. 296. 
This stage of the war was fundamental from the point of view of this analysis. When the shah annexed the lands dominated by Christians, he was forced to ask himself the question about his future religious policy concerning the new territories. The first step was obvious - the bishops of the Byzantine Empire had to be removed. The later attempts of the shah resembled the efforts of the Roman Emperors, successors of Constantine. The first Christian Emperor attempted to unite all followers of Christ into a single body that could be easily controlled by Constantine acting as pontifex maximus. The King of Kings had similar plans. Although his efforts to unite the Church of Armenia and the Church of Egypt were initially successful (some claim that it might be attributed to the fact that both communities were distant from each other and originated from the same movement of Monophysitism), the king came across some serious difficulties later on. Things became even more complicated due to the conversion of Shirin from the Assyrian Church of the East (so-called Nestorianism) to the Monophysitic Church of Antioch, the so-called Jacobite Church.

\section{Breakthrough Period 609-611}

Although the real change took place in the above-mentioned period (before and after the capture of Jerusalem), the origins of these events date back to a much earlier period. The legend of the cross, kept at the palace of the queen who supported Monophysitism after the capture of Jerusalem by the Persian troops, was supposed to consolidate her position among all followers of Christ. The queen, who cherished the relic respected by all Christians, was to be a symbol of Christian unity. Her role in the events that took place after the capture of Jerusalem by the Persian Empire is, nevertheless, much less obvious. The reign of Chosroes II was the time when the first cruel persecutions of Christians occurred as they had refused to consent to the religious policy of the King of Kings, and the role of Shirin in these events remains unclear. The Assyrian Lives of the Nestorian Martyrs laid blame on Shirin and the royal physician, Gabriel. It apparently raised some suspicions among other Christians.

\section{The Death of Chosroes II}

On 12 December 627, Heraclius defeated the Persian army in the battle of Nineveh and advanced towards Ctesiphon. He plundered the capital and the shah's palaces. Meanwhile, in February, the Emperor learned of the coup in Persia, which was nothing new in the kingdom. The shah was imprisoned and the king's own son, Siroes, was crowned. According to Theofanes, on facing the defeat the King of Kings decided to name Shirin's son, Merdanshah, the heir to the throne. These plans endangered the position of the oldest son, Siroes. 
Brooding on general dissatisfaction and discouragement, he rebelled against his father. He imprisoned his father and murdered all his brothers in the presence of Chosroes. ${ }^{7}$ He was proclaimed king as Kavadh II on 24 February 628, released the Byzantine prisoners and proposed peace that restored the borders of the Empire to those before his father's invasion. He also returned the relics of the True Cross. A few days after the coronation, on 28 February, he gave his father to his opponents, the relatives of those condemned to death by the former shah. This is how Chosroes II died. The plot involved, in particular, the sons of the minister of finance, Yazdin, who was condemned to death by Chosroes (they released Siroes, organised the coup and participated in the shah's murder). ${ }^{8} \mathrm{He}$ was an Assyrian Christian, initially supported by the king, and subsequently ousted and murdered for his loyalty to the Assyrian Church of the East at the time when the King of Kings, under the influence of his wife, attempted to subordinate all Christian communities under a single Church of a secular ruler. The Christians of the East immediately gathered to elect a new Catholicos. Babai the Great, the effective head of the Church of the East during this time, declined, and the bishops elected and enthroned Isho Yahb II. At the same time, the Jacobites established a new bishop at Tikrit, the seat of the Maphrians, which was vacant for several years after the death of Samuel.

The coup failed to establish peace and order in the empire after the dramatic military conflict. The concessions of Kavadh II did not make him any more popular. Changes of rulers were evermore frequent. Kavadh II died in September 628 and the throne went to Ardashir II. The underage son of Kavadh II was overthrown by Sharbaraz, who was in turn deprived of power by Boran, a daughter of Chosroes II (summer 630). According to a legend, this is when Shirin died, murdered after poisoning Kavadh II according to a Christian legend ${ }^{9}$ or after her suicide over the grave of Chosroes II to avoid dishonour and marriage to Kavadh II - according to the Arabian sources. Queen Boran reigned for only one year. Then power went to Yezdegar III, one of Chosroes II's grandsons.

According to al-Tabari, it was Shirin that saved Chosroes II's grandson. This story is filled with many legendary motives. The prophecy was to warn the shah of death from the hands of his own children. Therefore, Chosroes II forbad his children to marry. Please note that unmarried young men were not respected in the Persian society. Shirin took care of one of the sons of the king, Shariyar, and allowed him to secretly marry one of her ladies. On learning about the marriage, the queen saved Shariyar and his son, Yezdegar III, from the anger of the King of the Kings, and Yezdegar III later became the last shah of Persia.

\footnotetext{
${ }^{7}$ Al-Tabari, History, p. 328f.

${ }^{8}$ Thomas of Marga, Book of Governors, p. 11f.

${ }^{9}$ Version of Isho Yahba II and The Chronicle of Seert.
} 


\section{The Birth of the Legend}

Let me explain the title of this presentation, which may be perhaps misleading. The legend of Shirin was born in the non-Syriac sources. Shirin was more often described by exceptionally talented Arabian writers and historians, including alTabari. The Persian writings, and most notably Shāhnāmeh, ${ }^{10}$ or Book of Kings, the epic by the Persian poet Firdausi, contributed greatly to the popularisation of the Shirin legend. In the modern era, Goethe added some beautiful verses to the legend of Shirin. All sources originate from outside the circle of Syriac Christians. Why? Let me present the reasons.

\section{Fear of Caesaropapism?}

We have now reached the key question of ecclesiology. The writings that date back to the times of Chosroes are filled with praise for Shirin. The letters written at the times of Catholicos Sabrisho', and later, in the West-Syriac circles, name Shirin as "our queen." This applies to the writings composed at the times when the queen supported a specific group of Christians and within a specific community only. These Christians felt very devoted to the queen and they spoke highly of her. However, in his story about Shirin (58), W. Baum first mentioned that the Syriac Christians, both representatives of the Assyrian Church and the West Syriac Church, were relatively restrained in their later writings about Shirin.

Let us name the sources. Shirin is mentioned in Synodikon and in the lives of the saints from the Persian period, in which the queen's image is positive. The same applies to the authors from the Assyrian Church from the time of the dispute over Henana (app. 602). Later sources, but still dating back to the same period, for example The Life of Sabrisho, a Catholicos, were much more

${ }^{10}$ Ferdousi (Firdausi, Abu'l-Kasim Mansur Tusi Firdawsi), a highly revered Persian poet. Ferdowsi was born between 932 and 942 in Tus, near Meshhed, in Khorasanin; he died in 1020 or 1025. He is the author of the great epic, Shāhnameh (The Book of Kings), where he presented the Iranian legends, tales, myths and chronicles. In his work, he tells the history of old Persia before the Arab conquest of the region; he presents the tradition of ancient Persia and glorifies the ancient kings, especially from the Sassanid era. He tells the stories of heroic battles between Persians and the mythical Turans occupying the peripheries of Middle Asia (probably Turkestan). Among the characters of Shāhnāmeh - the great Iranian kings, most notably from the Sassanid period - we also encounter Alexander of Macedon. The Book is composed of 48-60 thousand couplets (depending on the version). The Book was initially written by Daqiqi in ca. 976, who was the author of no more than 1,000 couplets. Both the couplets, and the title of the book, were then used by Ferdousi. The poet started writing Shähnāmeh when he turned 40. It took him 35 years to complete his work. The epic is written in an elevated, vivid and beautiful language. It contributed greatly to the development of the Persian language (at the times when the New Persian language was the language of ordinary people, and Arabic was used at the court and in administration) and also to the development of national consciousness. The Book of Kings is compared in its impact to the epic of Homer from ancient Greece. See http://pl.wikipedia.org/wiki/Ferdousi [17.05.2010]. 
restrained. They avoid praise and incidentally, the accounts mentioning Shirin were noticeably reticent. Their authors were in fact presenting facts (?) that might shed some negative light on the king's spouse. This is how we learn about the royal physician as well as the queen's anger and hot-temper.

In the later writings, the attitude of the Syriac Christians towards Shirin became much more ambivalent. In The Life of Patriarch Isho Yahb II, Shirin was said to poison Kavadh II (Siroes) in revenge for the death of her husband and her son, Merdanshah. This text is more important as it is identical with the account in The Chronicle of Seert, the anonymous historiographic text written by the followers of the Syriac Christians of the West, the Jacobites, in the circles supporting Monophysitism. Both texts originate from two hostile communities, but both describe the same events. The story of Siroes being poisoned by the queen inspired the black legend of Shirin as the poisoner. The widowed queen became a cruel female villain who used evil methods to take revenge - often referred to in the literature of the Eastern culture. In literature, women involved in public life and their influence on power were perceived negatively. In spite of the cultural context, this seems truly astonishing when two factors are taken into consideration. Shirin was in fact a Christian who openly declared her devotion to religion and was notorious for her support for other Christians. She used her position at the court to promote Christians to key positions, which were beyond their reach at the earlier period. The new Arabian authorities were not phylo-Christian, and therefore, one might expect that Christians would be fond of the times when their sister in faith was one of the most important figures in the Empire, and Christians were allowed to participate freely in public life. Secondly, the dawn of the Persian Empire was at the same time the beginning of the Arabian invasion. In the $9^{\text {th }}$ century, after a period of relative tolerance, the persecutions of Christians began, and their role in administration and society in general was slowly marginalized. From this perspective, the history of Shirin should be a flicker of hope, a symbol of dreams of a Christian state occupying the territories of the Near and Middle East. However, quite to the contrary, Shirin's story became a black legend. Why? It appears that this fact may be attributed to several factors. The negative perception of Shirin by Christians resulted from resentment towards women participating in public life, which was prevalent at that time. As mentioned before, women who gained power were always presented in the context of controversy and evil in the writings originating from the East, expressed in the saying, It is man who builds a state, it is woman who ruins it.

Let us discuss another issue, namely the attitude of the Christian communities towards relations between the secular power and the Church, which was decisive for the image of Shirin in the later Syriac hagiography.

This factor is applicable to the role of Shirin in the history of each Church in the Persian Empire. It was an important, determining role; however, equally 
complicated and uncertain. True, Shirin took care of her brothers in faith. However, both Churches experienced what is expressed by the old Polish saying, King's favours cannot be taken for granted.

The first community supported by Shirin, the Assyrian Church of the East, initially experienced assistance and support of the secular power, both missionary (shah's interventions in the Arabian Peninsula in the name of Christians) and financial. Numerous Syrians were professionally active at the court and occupied many new positions in addition to those occupations that had been available to Christians in the preceding era, such as physicians. They were slowly paving their way to the positions in the state administration. We know a few names of Christians appointed as senior officers at the court.

However, when the conflict concerning Henana occurred, the headmaster of the School of Nisibis, who preached Chalcedonian Christianity contested by some of his students and the episcopate, the state authorities decided to oust him. Let us make a closer examination of this story.

Henana of Adiabene (571-610) was a student of Abraham of Beth Rabban. As an exegete and the headmaster of the School, he continued to preach what his predecessor did. The volume of his writings (with two short letters and a few quotations that have survived until the present times) was truly impressive. His Christological attitudes resembled the Greek, Byzantine tradition, which was deplored by some students in Nisibis, most notably by Elias who established a rival school. At that time, Sabrisho, an alumnus of the school of Nisibis and a student of Abraham of Kashkar, was appointed as a new Catholicos in opposition to the bishops. He immediately held a synod and anathematized the opponents of Theodore of Mopsuestia. The new Bishop of Nisibis, Gregory, explicitly named and condemned the writings of Henana of Adiabene as contesting the exegetic Antioch tradition. Henana appealed to the Catholicos who disagreed with the excommunication, which was nevertheless supported by the other bishops. Meanwhile, Shirin made a strange decision. When unrest began as the result of the bishops' decision, Sabrisho' deposed the bishop in an attempt to ease the tension, which caused the opposite consequences. ${ }^{11}$ It appeared logical that if the patriarch supported Theodore of Mopsuestia being called an exegete, at the same time he rejected the exegesis that was in opposition to the Antioch tradition and that's why he should support the bishop and not the headmaster! However, Sabrisho' acted in a quite contrary manner. His decision resulted in the intervention of the state authorities, and Bishop Gregory was ordered to abandon Nisibis and Henana.

These actions of the Catholicos might have been explained by the activities of Shirin. Her decisions were influenced by Gabriel of Shiggar, a royal physician,

\footnotetext{
${ }^{11}$ The Chronicle of Seert, Patrologia Orientalis IV/3, V/2, VII/2, XIII/4.
} 
who was in opposition to the Catholicos Sabrisho' as the result of being excommunicated after marrying two women, both pagans. Despite Shirin's attempts, the Catholicos refused to revoke the excommunication. Then Gabriel of Shiggar became a staunch Monophysite. (Note that The Syriac Chronicle claims that he first converted into the Jacobite Church, and then he married. In other words, the later Jacobite writings negatively judged the role of Gabriel in an attempt to live down the disgrace of supporting an overt bigamist.) The change of religious opinions and religious membership explains Gabriel's support for Henana, who covertly criticised the assumptions of the Antioch exegesis and supported the Alexandrian exegesis, which in fact brought him close to the Monophysites, although numerous contemporary researchers find him closer to the Chalcedonian Christianity, based on his remaining legacy that has survived until present. The concept of Henana's writing being orthodox is more satisfactory in relation to the assumptions of the School of Nisibis and the entire tradition of the Church of the East, which perceived the Chalcedonian Dyophysitism as more related to the Alexandrian Monophysitism. However, the attack on the Antioch exegesis and its supporters: Theodore, Diodorus or Nestorius, and the questioning of their roles, was the first step towards changing the doctrinal direction of the Church of the East. The influence of Gabriel made the synodical decision to excommunicate Gabriel null and void. The majority of the students left the school. That took place when Sabrisho' was the Catholicos. Some students went to the competitive school in Nisibis, established by Elias (Bet Sahde), the others went to Mont Isla or moved to the school of Balad, or travelled to various cities in Persia, where they propagated the idea of schools similar to that of Nisibis. ${ }^{12}$ Only a few students remained faithful to the original School of Nisibis.

In the meantime, Sabrisho baptised the king of the Arabs, Numan III, although he was not in favour of the monarch (he refused to support the shah in the rebellion). The Arab king died in a coup inspired by the Persian court (according to Elias of Nisibis), which inflamed the relations with the patriarch. Although the King of Kings supported Shirin's petition for the reconstruction of the monastery in Ctesiphon at the request of the patriarch; however, soon after the death of Sabrisho', the monastery was given to the Jacobites. Another probable foundation of the queen was the monastery in Hulwan, which was associated with Shirin by Thomas of Marga, without mentioning the queen's name. It is another fascinating element in the story of the wife of the King of Kings. Her name was omitted, which is very meaningful. According to the tradition, the names of founders were always mentioned and the intentional

${ }^{12}$ This is how the Syrian education system developed, which to a large extent contributed to the survival of the Christianity in Syria under the reign of Islam. 
omission of the name denotes a critical attitude towards the given individual. Shamta, a son of Yazdin, the minister of finance, collected liturgical books in Edessa to be given to the monastery. Initially, the monastery was supposed to be a place of worship of St. Sergius, which links it to Shirin and confirms her foundation.

After the death of Sabrisho in Persia, a synod was traditionally convened in Ctesiphon. The majority of the bishops supported Gregory of Kashkar, who was a banished metropolitan of Nisibis. They managed to convince the shah to support Gregory, but Gregory incurred the displeasure of Shirin, who wanted Gregory to be reconciled with the royal physician, which Gregory refused to do. The queen proposed Gregory of Phrat and took advantage of the fact that the bishops were debating in her palace. According to The Chronicle of Seert, the bishops decided to appoint Gregory but failed to stipulate which one, and presented their choice to the monarch. Shirin took advantage of the ambiguity of the name and presented Gregory of Phrat. The king was displeased and reluctantly supported the elected candidate, and later learned of the machinations of his wife and ordered the new patriarch to pay a huge contribution in return for the liturgical books seized during the war in Dara. In addition, after the death of Gregory, Chosroes did not forget the events of the previous election and refused to consent to the election of a new Catholicos. Babai the Great became the chief administrator. At that time, there were rumours at the court that a Monophysite might be nominated as Catholicos. Was it just a gossip written down by the annalists? A few facts can be quoted in support of such a state of affairs; furthermore, it might have been some intentional policy of the state as evidenced in the later decisions. Shirin invited Maruth of Takrit, a maphraian, the superior of the Monophysites in Persia, to visit the Assyrian monasteries in the capital city of Ctesiphon and to introduce the Syriac liturgy in its Jacobite version there. The new Catholicos was elected and the monastery returned to the Church of the East only after the death of Chosroes II and loss of power by Shirin.

After the Phokas rebellion, Chosroes began war against the Byzantine Empire. Initially, he managed to annex some major territories. Please note that the majority of the Jacobites in Persia were exiles from Antioch abducted by Chosroes I. The new wars increased the number of worshippers, and absence of any countermeasures on the part of the Church of the East made it easier to canvass new followers.

During the military campaign the shah ordered the banishment of the Chalcedonian bishops, who were replaced with the Jacobite ones (Patriarch Michael the Syrian, a Jacobite), claimed that the local population in Edessa refused to accept a "Nestorian" and a Jacobite candidate was instated. This appears to be an organized action of the court and the Jacobite senior clergy. From 609 the shah made regular attempts to substitute bishops on the newly annexed 
territories: the Melkites and the Nestorians were substituted with the Jacobites or at least the bishops devoted to the king and supporting Monophysitism.

The so-called synod of Persians under the auspices of the shah was supposed to establish a united Church of all Christian communities in the territory of the entire Empire, both native and annexed in the course of the campaign against the Byzantine Empire. Nevertheless, the historical sources are very scarce, and these events were described by an Armenian historian only, a bishop that lived several decades later. ${ }^{13}$ After the annexation of Alexandria, the shah made a public announcement that he would not elect a new Catholicos until the Church of the East rejected the Nestorius' doctrine. It was a threat that in fact meant that a superior from outside the Church could be appointed. At the same time, the shah continued to pursue the establishment of a union of the Churches of Alexandria, Armenia and the Jacobites, which was formally created in 615 (the union between the Church of Armenia and Egypt). These deeds were apparently inspired by the King of Kings. He wanted to subordinate the Church and was not interested in any theological discussions. After the death of Gabriel of Singar, the influence of Monophysitism waned. A few more events revealed tensions in the relationships between the king and the Jacobites. When Anastasius II of Antioch, a Monophysite patriarch, attempted to establish a bishop within his own territory, according to the laws in force, Samuel, the maphraian of Takrit, put forward his own candidate. The shah supported the latter and the patriarch was forced to retreat. After the death of Samuel in 624, the shah allowed the maphraian to be appointed, and the Jacobite Church had to wait until the death of the monarch to establish its representative in the capital (the same as the Assyrian Church). Another problem was that the church tradition was completely neglected and the capitals were subordinated, contrary to what the tradition taught. Those events were alarming and in addition, after the invasion of the Byzantine Emperor Heraclius in 628, the shah imposed new taxes in the native Persian territories to be able to support his army. He also seized and confiscated the belongings of the Jacobite Church. The "honeymoon" soon turned into a nightmare. Let us quote here an interesting passage of Bar Hebraeus quoted in The Syriac Chronicle, who said that in the face of a Byzantine reconquest God set the Jacobites free from slavery through the hands of Arabs! ${ }^{14}$ The shah was entirely omitted, which appears meaningful and supports my thesis: both Churches "learned a severe lesson" in the alliance with the throne.

The account of Babai the Great in Life of St. George presents a martyr-like devotion of the Assyrian Church followers to their own tradition - exemplified

${ }^{13}$ He took part in the synod in Dwin, 645.

${ }^{14}$ Gregorii Barhebrcei Chronicon ecclesiasticum, ediderunt, latinitate donarunt annotationibusque theologicis, historicis, geographicis et archeologicis illustrarunt J. B. Abbeloos et T. J. Lamy, Lovanii 1872, vol. 1, p. 274. 
in the martyrdom of St. George, who was crucified on 14 January 615 after eight months of torture and imprisonment. The queen is not mentioned at all whereas the Armenian sources of that time describe Shirin as a pious queen.

The final conclusions are as follows. One element is common - both Christian communities sooner or later noticed that the status of a state religion was both an opportunity and a threat. Each Christian community referred to the Fathers of the Church, whose theological careers were interrupted by the interference of the imperial authority in the Roman Empire. Each Christian community was persecuted at that time. In the Byzantine Empire, the consequences of a close union between both institutions were clearly visible. In other words, each Church knew that an alliance with the secular power required extensive compromises, not only in terms of the doctrine but also moral ones. The same problems and difficulties appeared in the Persian version of the alliance. Queen Shirin was also affected, and from now on tended to be perceived from a negative perspective.

The Muslims or followers of Zoroastrianism perceived her as a remarkable woman of strong will, capable of influencing the fate of the state. She appeared as an exceptional and outstanding personality. The question of her impact on the Church was of secondary importance. Some Muslims were already accustomed to the amalgamation of religious and secular power. The position of Shirin and her dealings at the court were apparently considered non-controversial. The subordination of Christians to the secular state made the queen even more distinguishable. Thus she became a legend.

On the other hand, the Christians of the Orient learned to live in separation from the secular power. In the period from the $7^{\text {th }}$ until the $12^{\text {th }}$ centuries, they managed to maintain more or less friendly relationships with the caliphate. Persecutions obviously took place; however, much depended on personal relations. The Persian times were similar; however, the doctrine was much less interfered with. If there arose any doctrinal dispute, it was related to the defence of the faith, the Christian testimony. Paradoxically, the Christian Churches found this situation much easier to handle. 